Deep Sea Research Part II: Topical Studies in Oceanography

November 2017, Volume 145, Pages 142-152

http://dx.doi.org/10.1016/i.dsr2.2016.04.013

http://archimer.ifremer.fr/doc/00332/44363/

(c) 2016 Elsevier Ltd. All rights reserved.

\title{
Marine litter in submarine canyons of the Bay of Biscay
}

\author{
Van Den Beld Inge ${ }^{1,{ }^{*}}$, Guillaumont Brigitte ${ }^{1}$, Menot Lenaick ${ }^{1}$, Bayle Christophe ${ }^{1}$, \\ Arnaud-Haond Sophie ${ }^{1}$, Bourillet Jean-Francois ${ }^{2}$
}

\author{
${ }^{1}$ Ifremer, Centre de Brest, EEP/LEP, CS 10070, 29280 Plouzané, France \\ ${ }^{2}$ Ifremer, Centre de Brest, REM/GM, CS 10070, 29280 Plouzané, France \\ * Corresponding author : Inge Van Den Beld, Tel.: +33 02982240 40; fax: +33 0298224757 ; \\ email address : Inge.van.den.Beld@ifremer.fr
}

\begin{abstract}
:
Marine litter is a matter of increasing concern worldwide, from shallow seas to the open ocean and from beaches to the deep-seafloor. Indeed, the deep sea may be the ultimate repository of a large proportion of litter in the ocean.

We used footage acquired with a Remotely Operated Vehicle (ROV) and a towed camera to investigate the distribution and composition of litter in the submarine canyons of the Bay of Biscay. This bay contains many submarine canyons housing Vulnerable Marine Ecosystems (VMEs) such as scleractinian coral habitats. VMEs are considered to be important for fish and they increase the local biodiversity. The objectives of the study were to investigate and discuss: i) litter density, ii) the principal sources of litter, iii) the influence of environmental factors on the distribution of litter, and iv) the impact of litter on benthic communities.

Litter was found in all 15 canyons and at three sites on the edge of the continental shelf/canyon, in 25 of 29 dives. The Belle-île and Arcachon Canyons contained the largest amounts of litter, up to 12.6 and 9.5 items 100 images -1 respectively. Plastic items were the most abundant (42\%), followed by fishingrelated items $(16 \%)$.

The litter had both a maritime and a terrestrial origin. The main sources could be linked to fishing activities, major shipping lanes and river discharges.

Litter appeared to accumulate at water depths of 801-1100 m and 1401-1700 m. In the deeper of these two depth ranges, litter accumulated on a geologically structured area, accounting for its high frequency at this depth. A larger number of images taken in areas of coral in the shallower of these two depth ranges may account for the high frequency of litter detection at this depth. A larger number of litter items, including plastic objects in particular, were observed on geological structures and in coral areas than on areas of bare substratum. The distribution of fishing-related items was similar for the various types of relief.
\end{abstract}


Litter items were mostly colonised by scleractinian corals and hydroids. Several fish species and a lithodid crab seemed to associate with the accumulated litter.

This extensive study showed litter to be widely distributed in the submarine canyons of the Bay of Biscay. These findings increase our understanding of the distribution of litter, its composition and accumulation and its impact on benthic communities.

Keywords : Litter, Anthropogenic impact, Canyons, Deep sea, Bay of Biscay, ROV, Towed camera

\section{Introduction}

The impact of human activities on the deep-sea environment has increased over recent decades, and this trend is predicted to continue in the near future (Ramirez-Llodra et al., 
2011). The exploitation of living, mineral and energy resources are of particular concern, but there is also a growing body of evidence that litter is common and widespread, even in the deepest parts of the ocean (Miyake et al., 2011).

Litter on beaches and items floating on the surface of the ocean have been extensively studied (Galgani et al., 2015; Ryan, 2015). The interaction of this debris - especially plastics - with turtles, sea birds and marine mammals, through suffocation, ingestion and entanglement has been widely in the literature (Kühn et al., 2015; Ryan, 2015). By contrast, little is known about the amount, distribution and composition of litter in the deep-sea environment, and its impact on deep-water habitats and benthic communities (Galgani et al., 2015; Miyake et al., 2011), although increasing numbers of studies are being undertaken to explore these issues (e.g. Galgani et al., 2015, Pham et al., 2014, Ramirez-Llodra et al., 2013). The studies carried out to date have indicated that plastic items predominate, at least in the Bay of Biscay (Galgani et al., 2000; Pham et al., 2014), four Portuguese canyons (Mordecai et al., 2011), several parts in the Mediterranean (Ramirez-Llodra et al., 2013; Tubau et al., 2015), the Gulf of Mexico (Wei et al., 2012), and along the shelf and slope of the west coast of the US (Keller et al., 2010), particularly in the Monterey Canyon (Schlining et al., 2013). Plastic longlines, originating from the fishing industry, were the main type of litter observed in the Azores (Pham et al., 2013) and off the coast of California (Watters et al., 2010), whereas ropes and gill nets were the most frequently observed items on the coral mounds off the Irish coast (Grehan et al., 2005). Fishing gear also dominated the litter found on the seamounts of Gorringe Bank (NE Atlantic; Vieira et al., 2015), the Tyrrhenian Sea in the Mediterranean (Angiolillo et al., 2015) and off the coast of South-East Africa (Woodall et al., 2015).

Submarine canyons along continental margins may act as a conduit for the transport of marine litter from shallower to deeper waters, or as a sink, retaining the litter in the deep sea (Mordecai et al., 2011; Pham et al., 2014; Schlining et al., 2013). Based on submersible video 
surveys in the Bay of Biscay, Galgani et al. (2000) reported higher densities of marine litter at bathyal depths in submarine canyons than on the continental shelf.

There are about 135 submarine canyons along the continental margin of the Bay of Biscay (Bourillet et al., 2006). These canyons host many Vulnerable Marine Ecosystems (VMEs) constructed by corals, sponges and oysters (De Mol et al., 2011; Huvenne et al., 2011; Reveillaud et al., 2008; Van Rooij et al., 2010). VMEs are considered to be functional and biodiversity 'hotspots', providing structural complex habitats that locally enhance the diversity and biomass of benthic communities (Buhl-Mortensen et al., 2010). Cold-water coral reefs, in particular, are thought to be important for many fish species (Costello et al., 2005; Roberts et al., 2006), as they provide shelter, feeding sites, spawning grounds (Auster, 2007; Sulak et al., 2007), and nursery areas (Baillon et al., 2012). However, the species responsible for the construction of these VMEs may, like geological structures (e.g. boulders and rocky outcrops; Schlining et al., 2013; Watters et al., 2010), trap litter (Bergmann and Klages, 2012; Galgani et al., 2000).

The principal human activities in the Bay of Biscay are fishing and shipping. The French and Spanish fishing fleets operate in this area, with the French (deep-sea) fleet targeting grenadiers (Macrouridae spp., especially Coryphaenoides rupestris), black scabbard fish (Aphanopus carbo), monkfish (Lophius spp.) and langoustines (Nephrops norvegicus) in particular (ICES, 2015). This part of the Atlantic Ocean also hosts a number of commercial and recreational shipping lanes. Human activities can have major detrimental effects on VMEs, which are fragile and easily disturbed, and recover only slowly, if at all (Althaus et al., 2009; Williams et al., 2010).

There is a need to determine what types of litter are present and their distribution, if we are to understand their impact on VMEs. We used footage acquired with an ROV and a towed camera system between 2009 and 2011 to estimate the amount of litter, its composition and 
distribution within the canyon systems of the French part of the Bay of Biscay in the NorthEast Atlantic Ocean. The objectives of this study were: i) to determine the density of litter, ii) to establish the principal sources of litter, iii) to consider the influence of environmental factors on the distribution of litter within and between canyons, and iv) to investigate the impact of litter on benthic communities.

\section{Material and methods}

\subsection{Study site}

The Bay of Biscay is part of the North-East Atlantic Ocean located to the west of France and the north of Spain. It includes the Armorican and Aquitaine margins, which we studied here, and it is bounded by the Celtic margin in the north, and the North Iberian margin in the south. The Armorican margin extends from the Berthois Spur to the Conti Spur, with a broad continental shelf (up to $200 \mathrm{~km}$ ) and a steep, canyon-dominated slope. By contrast, the Aquitaine margin extends from the Conti Spur to the Capbreton Canyon, and has a narrow shelf $(70 \mathrm{~km})$ and a smooth slope (Bourillet et al., 2006).

\subsection{Data collection}

Data were collected during two cruises on the R/V Pourquoi Pas? (Ifremer, France) BobGeo in 2009 (Bourillet, 2009) and BobEco in 2011 (Arnaud-Haond, 2011) - and one cruise on the R/V Le Suroitt (Ifremer, France) - BobGeo 2 in 2010 (Bourillet, 2010). The main objectives of these cruises were to study VMEs and/or geological features in canyons of the Bay of Biscay. Fifteen canyons were included in this study, mainly along the Armorican 
margin with the exception of the Arcachon Canyon located on the Aquitaine margin. In total, 29 dives were undertaken, 26 of which took place within canyons. The remaining three dives took place on the edge of the continental shelf/canyon (Table 1).

The Scampi towed camera system was used to collect data during 17 dives, and the Victor 6000 ROV during 12 dives (Table 1). The Scampi is equipped with a Nikon D700 photo camera directed vertically downwards. The system was towed at a mean speed of 0.9 knots, about 2 to $3 \mathrm{~m}$ above the seafloor. Photographs were taken at intervals of 10 to 90 seconds.

The Victor 6000 has multiple cameras. For the purpose of this study, we used the downwardfacing video camera (Sony FCB-H11). For comparison of the footage obtained with the ROV and the images taken by the towed camera, frame-grabs were taken from the video footage at one-minute intervals, with ADELIE annotation software. These frame-grabs were analysed in the same way as the photographs obtained with the towed camera system. Hereafter, we use the term 'images' to refer to both frame-grabs from the ROV and photographs from the Scampi. We obtained a mean of 5.8 images $100 \mathrm{~m}^{-1}$ with the ROV (after averaging over all dives), and 5.3 images $100 \mathrm{~m}^{-1}$ with Scampi.

Metadata (image name, time code and latitude/longitude) were recorded with ADELIE software, for both the towed camera and the ROV.

A depth value was extracted for each image from Digital Terrain Models, with grid sizes of 15, 25 or $125 \mathrm{~m}$ (Bourillet et al., 2012). These depth values were used to calculate the mean, minimum and maximum water depth of each dive. The mean depth of the dives was between 228 and $1598 \mathrm{~m}$ (Table 1), with a minimum water depth of $223 \mathrm{~m}$ and a maximum water depth of $2359 \mathrm{~m}$. 


\subsection{Data analysis}

Images were subjected to quality control to ensure that litter items were reliably identified and counted. Two criteria were used for quality control: i) altitude; images were excluded if they were taken less than $1 \mathrm{~m}$ or more than $5 \mathrm{~m}$ above the seafloor, and ii) image quality; images were excluded if poorly focused, taken in low-light conditions or with a high particle load.

Each image was annotated for three sets of criteria: i) marine litter, ii) the fauna colonising the marine litter, and iii) seafloor structures. Litter items were identified and allocated to one of six categories: 'Plastic', 'Fishing-related items', 'Cables and ropes', 'Glass bottles', 'Other items' and 'Unidentified items' (Table 2). The category 'Fishing-related items' included only items that could confidently be linked specifically to fishing activities. The fishing fleet may also discard plastic items, glass bottles or cables and ropes, but it is not possible to affirm a particular origin for these categories. Thus, we assigned non-specific plastic items, such as plastic bags and sheets to the 'Plastic' category, longlines to 'Fishing-related items' and rubber and metal products to 'Other items' (Table 2). If a particular item was visible on more than one image, it was counted only once, to prevent duplication and ensure a conservative estimate.

The presence or absence of colonising fauna was recorded. The colonising fauna was identified to the lowest possible taxonomic level. Mobile species, such as ophiuroids and crinoids, were recorded as colonising fauna only if they were found in or on the litter. Highly mobile species, such as fish and large crustaceans, were recorded interacting with litter items if the distance between the species and the item did not exceed about two body lengths.

The seafloor structure criterion was used to investigate the influence of the local relief on the distribution of litter. Seafloor relief may result from the construction of biological structures such as corals, sponges and xenophyophores, or geological structures, such as pebbles, 
cobbles and rocky outcrops (Table 3). Four categories were defined: "Corals", "Other biological structures", "Geological structures" and "Bare substratum".

Litter densities were quantified and normalised per 100 images (litter items 100 images $^{-1}$ ). The contribution of each type of litter to the total number of items encountered during a complete dive was calculated as a percentage. In most cases, only one dive was performed per canyon. If multiple dives were performed within the same canyon, the numbers of items attributed to each category were averaged between dives before the calculation of percentages. We included multiple dives for a given canyon if the dives took place far enough apart to ensure that they did not cross paths and none of the items would be counted twice.

The presence or absence of litter on each image was also used to investigate the difference in litter densities with water depth. The percentage of images showing litter was calculated from the total number of images for each 300-m depth class. These depth classes were chosen to optimise the trade-off between the number of classes, the class interval and the number of observations in each class in the depth range of our dataset (water depth of $\sim 200-2400 \mathrm{~m}$ ). Seven depth classes were chosen of which two depth classes were merged into a single class, because they contained too few images for separate analysis (> $1701 \mathrm{~m} \mathrm{depth})$, resulting in six classes in total. A chi-squared test was used to assess the influence of water depth.

The density of litter in each seafloor structure category was normalised on the basis of the total number of images in the corresponding category and is expressed in litter items 100 images $^{-1}$. The percentage of images showing litter was calculated from the number of images showing at least one item of litter and the total number of images in each category. A chisquared test was used to assess differences in litter abundance between categories on the basis of presence/absence data for each image. 


\section{Results}

\subsection{Distribution and composition of litter}

In total, 198 individual litter items were recorded on the 6255 images analysed (Table 1). We observed a mean of 3.2 items 100 images $^{-1}$ over the entire Bay of Biscay. However, the distribution and densities of items differed considerably between dives and between canyons. Litter items were observed in 25 of the 29 dives (86\%). Litter was found in all 15 canyons and in the three dives located at the edge of the continental shelf/canyon. However, no litter was found in four single dives (Sorlingues Canyon, BobEco, dive 472; Chapelle Canyon, BobGeo, dive 3; Odet Canyon, BobGeo, dive 10; and Arcachon Canyon, BobGeo 2, dive 2). The maximum number of litter items detected in a particular dive was 30 , equivalent to 39.5 items 100 images $^{-1}$, for the Arcachon Canyon (BobGeo 2, dive 3). However, litter density was highest in the Belle-1̂le Canyon (12.6 items 100 images $^{-1}$; BobGeo, dive 11) if we averaged the findings for the three dives in the Arcachon Canyon. The second highest mean density of

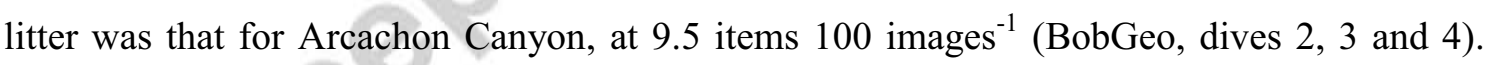

The third highest mean density of litter was that of Morgat Canyon (8.9 items 100 images $^{-1}$; BobGeo, dives 5 and 6).

Overall, $42 \%$ of the items observed were made of plastic, mostly bags or sheets (Fig. 1A; Fig. 2). Fishing-related items, such as nets and longlines (Fig. 1B) were the second most frequent category of items found, accounting for $16.2 \%$ of all the litter items observed (Fig. 2). "Cables and ropes" (Fig. 1C) accounted for 6.1\% of litter items. "Glass bottles" (Fig. 1D), "Other items" and "Unidentified items" accounted for 8.6, 15.2 and 11.6\% of litter items, 
respectively (Fig. 2). The "Other items" category included an artillery shell, ceramics and metallic items (Fig. 1E).

The distributions of the various types of litter differed in the Bay of Biscay (Fig. 3). Plastic items were observed mostly in the central and southern parts of the Bay of Biscay. Fishingrelated items and cables and ropes were found all over the Bay of Biscay, but their relative abundance was highest in Ars Canyon (66.7\% of all litter items found in this canyon). Glass bottles were observed predominantly in the canyons off the coast of southwest Brittany, with the highest percentages obtained for the interfluve between the Douarnenez and Morgat Canyons (35.7\%), and for Crozon Canyon (25.0\%). The highest percentages for "Other items" were obtained in the centre of the Bay of Biscay (Douarnenez-Morgat: 35.7\%; southern-most location on the shelf near Odet Canyon: $30.8 \%$ ).

Two sites of litter accumulation were identified in Arcachon Canyon: i) a fishing net trapping at least 20 pieces of plastic and ii) a longline, plastic items, cloth and an item resembling a piece of glass.

\subsection{Depth classes}

The percentages of images showing litter items were highest for the '801-1100 m' and '14011700 m' depth classes, at $3.2 \%$ and $7.4 \%$, respectively (Fig. 4). The percentages of images showing litter items were less than $2 \%$ for all other depth classes. Litter density differed significantly between depth classes $\left(\chi^{2}=34.5382 ; \mathrm{df}=5, p<0.001\right)$. We initially thought that this difference might be the result of litter accumulation at two sites within Arcachon Canyon, both in the 1401-1700 $\mathrm{m}$ depth class. However, this difference remained significant after the removal of these accumulations from the analysis $\left(\chi^{2}=17.9053 ; \mathrm{df}=5, p=0.003\right)$. 


\subsection{Influence of seafloor structures}

The relief created by geological or biological structures influenced the distribution of litter (Table 4). The observed distribution of litter between seafloor structure categories was significantly different from a random distribution $\left(\chi^{2}=44.363\right.$, df $\left.=3, p<0.0001\right)$. The relative frequency and density of litter were higher in areas with elevated geological structures $\left(4.3 \%, 9.9\right.$ items 100 images $\left.^{-1}\right)$, than in areas with other types of relief (corals: $3.9 \%, 4.5$ items

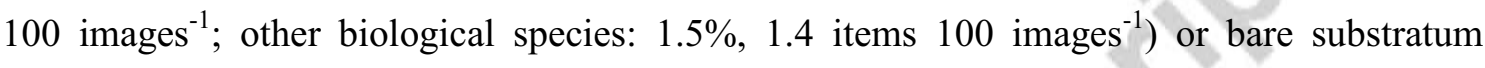
$\left(1.3 \%, 1.5\right.$ items 100 images $\left.^{-1}\right)$.

The accumulations in the Arcachon Canyon mentioned above were located next to rocky outcrops, which largely accounted for the influence of geological structures. When these accumulations were removed from the analysis, the number of images showing litter decreased to 11 , leading to decreases in average litter density to 3.4 items 100 image $^{-1}$ and the percentage of images showing litter to $2.5 \%$ (based on 435 images from the "geological structures" category). However, even with the elimination of these accumulations, the influence of seabed structure on litter distribution remained significant $\left(\chi^{2}=39.3524, \mathrm{df}=3, p\right.$ $<0.0001)$.

The number of items allocated to the different litter categories differed between seafloor structures (Fig. 5). There were too few litter items in areas in which the relief was constructed by organisms other than corals for valid chi-squared tests. We therefore merged this category with the 'corals' category. The composition of the litter associated with the three remaining types of seafloor structure (biological structures, geological structures and bare substratum), differed significantly from a random distribution $\left(\chi^{2}=22.3062, \mathrm{df}=10, p=0.01\right)$. 
This difference was driven by differences in the relative abundance of glass bottles, plastic and other items. Glass bottles were absent from areas of geological structure and were more abundant in areas in which the relief was constructed by biological organisms. The relative density of plastic items was lower on bare substratum than on biologically or geologically structured areas. "Other items" were observed predominantly on bare substratum.

By contrast, fishing-related items were more evenly distributed, with percentages of $41 \%$ for biological structures, $59 \%$ for geological structures and $29 \%$ for bare substratum.

The distribution of seafloor structures differed between the depth classes described above (Fig. 6). The relative abundance of seafloor structures formed by corals was higher in the '801-1100 m' and '>1701 m' water depth classes $\left(\chi^{2}=1147.897\right.$, df $\left.=15, p<0.0001\right)$. Interestingly, the accumulations observed at depths of 1401 to $1700 \mathrm{~m}$ in the Arcachon Canyon were located in an area in which the relief is formed by geological structures, even though geological structures were rare in this depth class.

\subsection{Colonising fauna}

Twenty-seven items (13.6\% of the items observed) were colonised, mostly by sessile suspension feeders. Plastic items, fishing gear, ropes and cloth were colonised by actinians (at least three different species; e.g. see Fig. 1A). Scleractinians (Madrepora oculata, Lophelia pertusa and/or solitary corals) and hydroids generally colonised fishing gear, such as longlines, nets and traps, and cables. One cable was also found to be encrusted with sponges and serpulids. The artillery shell was colonised by oysters. Mobile species, such as crinoids and ophiuroids were observed on plastic materials, fishing gear and cables. Single occurrences of a holothurian next to a part of a trawl net, the echinoid Cidaris cidaris in a fishing net and an unidentified echinoid (probably Echinus spp.) on a cable were also 
recorded. Crustaceans of the genus Munida were found to use plastic items and cloth as burrows. About 12 fish (Macrouridae spp., Synaphobranchus kaupii and Lepidion eques) and a lithodid crab were found close to a large fishing net and longlines. Another seven fish were found further away, but still less than five body lengths from the item. However, it was difficult to determine whether the fish in or very close to the net were still alive.

Sixty-four items $(32.3 \%)$ were either partly buried or covered by a very thin layer of sediment.

\section{Discussion}

\subsection{Litter density in the Bay of Biscay}

Marine litter is one of the qualitative descriptors for which goals have been set for the achievement of Good Environmental Status in the European Marine Strategy Framework, and it is one that needs to be tackled urgently (Galgani et al., 2013). Knowledge about the amounts, nature and origin of litter at the European scale is essential for the definition of priority areas and management strategies. However, it is often difficult to compare the results of different studies, due to the use of diverse methods for data acquisition and analysis. Trawling surveys can sample buried litter and small items but integrate litter distribution data over large distances which prevents precise localisation of each litter item recovered in the net. On the other hand, optical surveys can provide a precise geolocalisation of items as well as additional information about the local environmental and the biological setting, but only for visible macroscopic litter. In both cases, quantification of the area sampled or observed is an issue. For optical surveys, an estimation of the absolute size of an image requires lasers or precise information about the position and attitude of the vehicle (altitude, pitch, roll) and the 
camera (pan, tilt, zoom). In this study, we used cameras directed vertically downwards. This approach should, theoretically, provide more accurate estimates of absolute image size than approaches using a forward-directed camera. Unfortunately, the available information about the attitude of the Scampi was not precise enough for the accurate quantification of image size. In addition, the design and processing of optical surveys may complicate comparisons even further. Several studies have analysed still images (this study; Bergmann and Klages, 2012; Mordecai et al., 2011; Pham et al., 2014), whereas other have analysed a continuous video (Pham et al., 2013; 2014) or a combination of still and video images (Fabri et al., 2014). Image-based surveys, with non-contiguous images, provide a sub-sample of video surveys that does not capture the full range of the heterogeneity of litter distribution.

Aware that our optical, image-based surveys were likely to underestimate litter density, we still asked whether our results were in the same range as reported in previous studies, or more than an order of magnitude different. Based on the calibration of the ROV camera and the mean altitude of ROV dives (2.5 $\mathrm{m}$ above the seafloor), we estimated that the area of seafloor observed in each image was $6.6 \mathrm{~m}^{2}$. This value was used to extrapolate litter densities from the number of items 100 images $^{-1}$ to the number of items $\mathrm{km}^{-2}$.

In the Bay of Biscay, the mean litter density was 4,813 items $\mathrm{km}^{-2}$ and the litter density per dive ranged from 0 to 9,626 items $\mathrm{km}^{-2}$. Outliers of 15,643 (Morgat Canyon), 18,952 (Belleîle Canyon) and 59,412 (Arcachon Canyon) items $\mathrm{km}^{-2}$ were observed. Mean litter density in the canyons of the Bay of Biscay was an order of magnitude higher than the highest densities reported from trawling on the continental shelf (Galgani et al., 1995), confirming that canyons along continental margins act as a sink for marine litter (Pham et al., 2014). The range and mean densities of litter in our study were consistent with previous observations in canyons of the NE Atlantic and the Mediterranean Sea (Pham et al., 2014). The outlier values of density obtained for the Belle-île and Arcachon Canyons, $200 \mathrm{~km}$ and $75 \mathrm{~km}$ from land, respectively, 
were, however, unusually high, well above those reported for the Lisbon Canyon (6600 items $\mathrm{km}^{-2}, 27 \mathrm{~km}$ from land, Mordecai et al., 2011), and higher than, but not dissimilar to those reported for the La Fonera Canyon (15,057 items $\mathrm{km}^{-2}, 4 \mathrm{~km}$ from land, Tubau et al., 2015, thus establishing a new record for European canyons. The densities calculated here are also higher than those already reported for similar and nearby canyons in the Bay of Biscay. Pham et al. (2014) reported a litter density in Guilvinec Canyon two times lower than the one given in this study (3190 vs. 7521 items $\mathrm{km}^{-2}$ ) and a litter density for Whittard Canyon only one third of that obtained for the nearby Sorlingues Canyon in our study (140 vs. 602 items km²). These discrepancies may indicate the existence of methodological biases in these comparisons, which should be considered with caution. However, this study, like others, highlights considerable spatial heterogeneity in the distribution of litter, possibly reflecting the variability of and distance from sources, the shape and activity of the canyons and the roughness of the seafloor (Galgani et al., 2000; Mordecai et al., 2011; Tubau et al., 2015; Woodall et al., 2015).

\subsection{Influence of human activities on the nature and distribution of litter}

Litter on the deep-sea bottom may be of terrestrial or maritime origin. Terrestrial sources probably predominate for plastics, which, due to their buoyancy, can travel large distances before settling down on the seafloor (Bergmann and Klages, 2012; Pham et al., 2014). Mordecai et al. (2011) concluded that most of the litter in Lisbon Canyon probably came from the land, because this canyon is located close to the shore. Litter from the land can be transported into the sea by rivers, and thence to the canyon system. This process clearly occurs at the submarine extension of the Rhone into the Gulf of Lion in the Mediterranean Sea (Galgani et al., 2000), the discharges of the Tordera River into the western Mediterranean 
(Ramirez-Llodra et al., 2013; Tubau et al., 2015) and the Gironde estuary in the Bay of Biscay (Galgani et al., 1995). The predominance of plastic items among the litter observed in this and other studies (Galgani et al., 2000; Mordecai et al., 2011; Pham et al., 2014; Ramirez-Llodra et al., 2013; Schlining et al., 2013; Tubau et al., 2015) may indicate a major input of litter from terrestrial sources, but it is difficult to determine their precise source (Pham et al., 2014). The highest mean densities of plastics were observed in the Belle-île and Arcachon Canyons. The continental shelf is at its widest in the region of the Belle-île Canyon, but this section of the Armorican margin is probably under the influence of the Loire River (Jouanneau et al., 1999) and has a high abundance of litter (Galgani et al., 2000). The Arcachon Canyon may be affected by discharges from the Gironde estuary, which are directed to the south west (Jouanneau et al., 1999), because zones of litter accumulation are found in this direction but at some distance from the estuary (Galgani et al., 2000). The coastline facing the Belle-île and Arcachon Canyons also attracts large numbers of tourists and recreational sailors, potentially contributing significantly to the accumulation of plastics items in these two canyons.

Litter of maritime origin is more easily traced because it consists of rapidly sinking debris, such as glass bottles (Ramirez-Llodra et al., 2013), and activity-specific material such as pieces of longlines, nets and traps from the fishing industry. The number of glass bottles observed was highest for the Crozon Canyon and for the adjacent canyons and interfluves to the south (the Morgat and Douarnenez Canyons). This area is crossed by a major shipping lane, extending from the west of Spain to the English Channel. Many of these glass bottles may have been discarded from ships, because the disposal of glass at sea is still permitted beyond the territorial waters of states ( $>12$ nautical miles from the nearest land; Annex V of the Convention for the Prevention of the Pollution from Ships MARPOL 73/78). Another major shipping lane in the Bay of Biscay crosses the canyon system near the Croisic and Belle-île Canyons. No glass bottles were observed in these canyons, but we cannot exclude 
the possibility that litter discarded from ships also contributed to the large amount of plastic items found in Belle-île Canyon.

Fishing activities are widespread throughout the Bay of Biscay (Lorance and Leonardi, 2011), and this is reflected in the observed distribution of fishing-related items. Fishing-related items were observed in 11 canyons and on the edges of the continental shelf near the Lampaul and Odet Canyons.

Most litter items, with the exception of plastic items, present in the canyons of the Bay of Biscay therefore probably originated from the maritime activities of the fishing, commercial and recreational sectors. These activities may also be a source of plastic items, but such items are unlikely to be of purely maritime origin, with many such items being transported from the land to the sea via rivers.

\subsection{Influence of environmental factors on litter distribution}

Marine litter is not distributed evenly over the deep-seafloor (Pham et al., 2014; RamirezLlodra et al., 2013). Environmental factors may modify the transport and permanent deposition of litter. These factors include currents, which interact with topographic features at various spatial scales and are a major driver of the distribution of litter (Galgani et al., 2000; Mordecai et al., 2011). Canyons, which funnel deep-water currents from the shelf to the abyss, have been identified as large topographic features likely to act as a conduit for litter transport, particularly for light plastics (Galgani et al., 2000; 1996; Mordecai et al., 2011; Ramirez-Llodra et al., 2011; Schlining et al., 2013). This hypothesis is confirmed by the predominance of plastic items among the litter observed in nine of the 15 canyons included in this study, consistent with the findings of other canyon-related studies (Mordecai et al., 2011; Tubau et al., 2015). Pham et al. (2014) found that litter densities were higher in submarine 
canyons than in other physiographic settings, such as continental shelves and seamounts, banks and mounds. The composition of litter in a submarine canyons is different compared to other settings. Half the items of litter found in submarine canyons were made of plastic (Pham et al., 2014), whereas only a small percentage of plastics were observed on seamounts (Pham et al., 2014; Vieira et al., 2015).

Within canyons, litter transport and accumulation vary with the natural dynamics of the canyon and the roughness of the seafloor (Schlining et al., 2013). As canyons are thought to act as conduits of both natural and anthropogenic materials, litter might be expected to accumulate towards the lower parts of canyons. However, analyses of the depth distribution of litter have not given consistent results between canyons. Some studies have reported an accumulation of litter at greater depths (Galgani et al., 2000; Schlining et al., 2013; Tubau et al., 2015), but others have reported an absence of a relationship between depth and litter distribution (Fabri et al., 2014; Mordecai et al., 2011; Ramirez-Llodra et al., 2013). Downslope accumulations of litter have been suggested in canyons actively carrying sediment towards the deep-sea fan (Galgani et al., 2000; Mordecai et al., 2011). Stronger dense shelf water cascading events may also explain the transport to and accumulation of litter at greater depths in the Cap Creus Canyon than in La Fonera Canyon, in the Western Mediterranean Sea (Tubau et al., 2015). In the canyons of the Bay of Biscay, litter density varied according to depth. Litter was most abundant in the middle depth classes ('801-1100 m' and '1401-1700 m') in our study. However, little is known about current dynamics in the canyons of the Bay of Biscay. Along the Armorican margin, current strength and direction are driven by internal tides, and net downslope currents have been recorded in the upper parts of the Guilvinec, Audierne and Blackmud Canyons, with instantaneous current speeds as high as $1 \mathrm{~m} \mathrm{~s}^{-1}$ (Khripounoff et al., 2014; Mulder et al., 2012). Net down-canyon currents extend to depths of $1500 \mathrm{~m}$ in the Audierne Canyon, whereas up-canyon currents predominate at this depth in the 
Blackmud Canyon. In both canyons, an alternation of up- and downslope currents suggests that particles should be trapped in these canyons (Mulder et al., 2012). This and the roughness of the seafloor (see below) may account for litter being most abundant in the middle of the depth range. Canyon dynamics may be different along the Aquitaine margin. In the Cap Ferret Canyon, just north of the Arcachon Canyon, the upper part of the canyon above $500 \mathrm{~m}$ depth, is a by-passing area, with sediments, and probably litter, passing straight through to accumulate in the middle region, at depths of 500 to $1500 \mathrm{~m}$ (Schmidt et al., 2014). The Arcachon Canyon has a distinctive morphology, more like a channel-levee system, with a broader canyon thalweg and very gentle flanks (De Chambure et al., 2013). Areas of deposition towards the lower part of the Arcachon Canyon may account for the accumulation of large amounts of litter, resulting in high densities for the 1401-1700 m depth class.

In addition to depth, complex biological and geological structures significantly influence the distribution of litter in the canyons of the Bay of Biscay. Indeed, geological features, such as ledges, sand dunes, terraces and boulder fields, and biological structures, such as corals, may trap litter and prevent its onward transport with the current (Galgani et al., 1996). More litter was seen in rocky areas than in sandy habitats or habitats with cobbles off California (Watters et al., 2010). In the Monterey Canyon, litter tended to accumulate in high-relief outcrops or in depressions (Schlining et al., 2013). Large numbers of Cladorhiza gelida sponges were frequently found entangled with plastic, due to their emerging characteristics (Bergmann and Klages, 2012). In the Bay of Biscay canyons, the relative abundance of plastics, which are thought to be particularly prone to transport by currents, was higher in complex habitats than on bare substratum. Moreover, these complex habitats were dominated by corals, particularly along the Armorican margin, where they occurred predominantly in the $801-1100 \mathrm{~m}$ depth class. In the lower part of the Arcachon Canyon, complex structures were rare, but the largest accumulations of litter in the 1401-1700 m depth class were nevertheless observed next to 
rocky outcrops. Seafloor roughness is thus a major driver of the local distribution of lighter marine litter, such as plastic items, which are trapped equally efficiently by biologically and geologically complex habitats.

Several environmental factors, such as current (speed and direction) and geomorphology, can influence the accumulation of litter. These factors may act at different scales, from the entire Bay of Biscay down to individual canyons and, even small geological and biological structures.

\subsection{Impact of litter on benthic communities}

Litter can affect marine species and habitats by entanglement, suffocation, ghost fishing and/or physical damages to the sessile fauna (Kühn et al., 2015; Ramirez-Llodra et al., 2011). In the Bay of Biscay, VMEs, such as coral habitats, were found to be hotspots of litter accumulation, especially plastics. There was no evidence of a direct impact of plastic items on the benthic communities. However, fibres and particles released by plastic degradation may eventually be ingested by the suspension-feeders that are dominant in coral communities (Thompson et al., 2004). The effect of such contamination remains unclear, but it may have a cumulative effect with other anthropogenic factors (fishing, chemical contamination, climate change), resulting in a significant impact on deep-sea coral communities.

Fishing-related items were found throughout the Bay of Biscay and, unlike plastics, were not preferentially associated with corals or with any other complex habitat. This suggests that fishing-related items may be too heavy for displacement by currents. However, 15 to $20 \%$ of the marine litter found in corals (including cable and ropes) was related to fishing activities, highlighting this additional, potentially strong pressure on the health status of corals. 
In addition to its negative impacts, marine litter may provide a new habitat locally favouring beta diversity. Litter was found to be colonised by marine species from various taxonomic orders in this study, as in others. For example, actinians were found to have colonised a plastic sheet (this study; Fig. 1A), serpulid worms have been found on a missile (Wei et al., 2012), hydroids have been observed on a metal oil drum (Mordecai et al., 2011) and the brachiopod Grypheus vitreus has been found on clinkers (Ramirez-Llodra et al., 2013). Litter items may provide protective structures for mobile fauna, fish in particular (Bergmann and Klages, 2012; Watters et al., 2010). In this present study, several fish (Macrouridae spp., $S$. kaupii and L. eques) and a lithodid crab species were seen in and around a large fishing net. The fish trapped in the net were probably dead, attracting the macrourids and S. kaupii, known to be scavengers (e.g. Cousins et al., 2013; Priede et al., 1990; and references therein). However, the net may also provide shelter, accounting for the presence of $L$. eques. Angiolillo et al. (2015) reported mobile species, such as crustaceans, echinoids and octopuses, using litter as a refuge, similar to Munida in our study.

It appeared that $13.6 \%$ of the observed litter items in the Bay of Biscay was colonised, which is much less than $80 \%$ of litter reported by Angiolillo et al. (2015) and 67\% reported by Bergmann and Klages (2012), of which the latter did not distinguish between colonisation or other interactions, such as entanglement. However, interactions between fauna and litter are rarely quantified in the literature and therefore the extent of litter colonisation or association remains largely unknown. The effects of such associations on the composition of benthic communities locally and regionally also remain to be determined. Such associations may increase local diversity, as seen in Portuguese canyons (Mordecai et al., 2011), but the replacement of existing species by other naturally occurring fauna can lead to non-natural changes to the composition of the local fauna (Bergmann and Klages, 2012), with effects on predation and competition for space and food. Colonisation may occur to such an extent that 
older litter items may eventually be completely covered by organisms, such as the reefbuilding scleractinian corals that cover the artificial substrate provided by oil rigs in the North Sea (Bell and Smith, 1999; Gass and Roberts, 2006).

The effects of litter on benthic communities thus remain unclear, but the risk of cumulative adverse effects and application of the precautionary principle should foster an increase in public awareness and the establishment of regulations to prevent litter entering the oceans. Awareness of the presence of VMEs and the negative impact of human activities on those ecosystems is increasing. This awareness is the first step towards the establishment of measures limiting the introduction of litter into the submarine canyons of the Bay of Biscay. The establishment of Marine Protected Areas (MPAs), marine reserves and/or no-take zones (Ramirez-Llodra et al., 2011) is among the measures that could be taken. There is currently only one such zone in the Bay of Biscay, the no-take zone of Capbreton Canyon (Delayat and Legrand, 2011; Sanchez et al., 2013). A consensus between policy makers, scientists, industries making use of the deep-sea environment (e.g. fisheries and oil and gas companies) and all other relevant stakeholders could be developed for this and other measures, such as stricter regulations on the disposal of rubbish.

\section{Conclusion}

An analysis of litter density and distribution on image footage showed litter to be widespread in the Bay of Biscay, with some of the highest densities ever found on European continental margins in the North-East Atlantic (up to 59,000 items $\mathrm{km}^{-2}$ ). This extensive study involved 29 dives in 15 canyons and at three other sites on the edge of the continental shelf/canyon. 
The litter in the Bay of Biscay is of both terrestrial and maritime origin. Plastic items were the most abundant type of litter, accounting for about $42 \%$ of the items observed, followed by fishing-related items $(16 \%)$.

The distribution of litter resulted from the interplay between litter sources, litter buoyancy and the nested scales of hydrodynamic processes. Some of the lighter plastic items probably arrived in the canyons from the Loire and Gironde rivers. These items would have been transported by large-scale currents to the shelf break and downslope. Within canyons, internal tides transported the light litter further downslope, until it eventually became trapped in areas of deposition, including complex biological and geological structures. Corals were found to be particularly favourable structures for the accumulation of plastic items. Glass bottles seemed to be linked to shipping activities, whereas fishing-related items were more evenly distributed both within and between canyons.

Fishing-related items were not preferentially associated with corals, but they nevertheless accounted for $15-20 \%$ of the debris in these habitats. Even though litter has been shown to provide a habitat or shelter for benthic species, the cumulative impacts of litter and other anthropogenic pressures, such as fishing and climate change, suggest that effective prevention measures should be implemented to limit the discarding of litter in the marine environment.

\section{Acknowledgements}

We would like to thank the captains and crews of the R/Vs Le Suroît and Pourquoi Pas? during the BobGeo (2009), BobGeo 2 (2010) and BobEco (2011) cruises. We also thank the Scampi/Victor6000 and scientific teams on board. All cruises were part of the EU FP7-funded CoralFISH project. The first author acknowledges funding from Région Bretagne and Ifremer. 
We would like to thank Mickael Drogou (Ifremer) for his help in determining the origin of cables and ropes. We thank Karine Olu (Ifremer) for her helpful comments on an earlier version of this manuscript. Finally, the authors would like to thank the two anonymous reviewers for their remarks, comments and suggestions, which helped us to improve this manuscript considerably.

\section{References}

Althaus, F., Williams, A., Schlacher, T.A., Kloser, R.J., Green, M.A., Barker, B.A., Bax, N.J., Brodie, P., Schlacher-Hoenlinger, M.A., 2009. Impacts of bottom trawling on deep-coral ecosystems of seamounts are long-lasting. Marine Ecology Progress Series 397, 279-294. Angiolillo, M., di Lorenzo, B., Farcomeni, A., Bo, M., Bavestrello, G., Santangelo, G., Cau, A., Mastascusa, V., Cau, A., Sacco, F., Canese, S., 2015. Distribution and assessment of marine debris in the deep Tyrrhenian Sea (NW Mediterranean Sea, Italy). Marine Pollution Bulletin 92, 149-159.

Arnaud-Haond, S., 2011. Compte-rendu de la campagne BOBECO sur le N/O Pourquoi Pas? Ifremer, Brest, France.

Auster, P.J., 2007. Linking deep-water corals and fish populations, in: George, R.Y., Cairns, S.D. (Eds.), Conservation and Adaptive Management of Seamount and Deep-Sea Coral Ecosystems. Univ Miami, Miami, pp. 93-99.

Baillon, S., Hamel, J.F., Wareham, V.E., Mercier, A., 2012. Deep cold-water corals as nurseries for fish larvae. Frontiers in Ecology and the Environment 10, 351-356.

Bell, N., Smith, J., 1999. Coral growing on North Sea oil rigs. Nature 402, 601-601.

Bergmann, M., Klages, M., 2012. Increase of litter at the Arctic deep-sea observatory

HAUSGARTEN. Marine Pollution Bulletin 64, 2734-2741.

Bourillet, J.-F., 2009. Compte-rendu de la campagne BOBGEO sur le N/O Pourquoi Pas?

Ifremer, Brest, France.

Bourillet, J.-F., 2010. Compte-rendu de la campagne BOBGEO2 sur le N/O LE SUROÎT. Ifremer, Brest, France.

Bourillet, J.F., de Chambure, L., Loubrieu, B., 2012. Sur les traces des coraux d'eau froide du golfe de Gascogne. 8 cartes géomorphologiques au 1/100.000. Quae (Ed.), France

Bourillet, J.F., Zaragosi, S., Mulder, T., 2006. The French Atlantic margin and deep-sea submarine systems. Geo-Marine Letters 26, 311-315.

Buhl-Mortensen, L., Vanreusel, A., Gooday, A.J., Levin, L.A., Priede, I.G., Buhl-Mortensen, P., Gheerardyn, H., King, N.J., Raes, M., 2010. Biological structures as a source of habitat heterogeneity and biodiversity on the deep ocean margins. Marine Ecology-an Evolutionary Perspective 31, 21-50.

Costello, M.J., McCrea, M., Freiwald, A., Lundalv, T., Jonsson, L., Bett, B.J., van Weering, T.C.E., de Haas, H., Roberts, J.M., Allen, D., 2005. Role of cold-water Lophelia pertusa coral reefs as fish habitat in the NE Atlantic, in: Freiwald, A., Roberts, J.M. (Eds.), Cold-Water Corals and Ecosystems, pp. 771-805.

Cousins, N.J., Linley, T.D., Jamieson, A.J., Bagley, P.M., Blades, H., Box, T., Chambers, R., Ford, A., Shields, M.A., Priede, I.G., 2013. Bathyal demersal fishes of Charlie-Gibbs Fracture 
Zone region (49-54 degrees N) of the Mid-Atlantic Ridge: II. Baited camera lander observations. Deep-Sea Research Part Ii-Topical Studies in Oceanography 98, 397-406. De Chambure, L., Bourillet, J.-F., Bartel, C., 2013. Geomorphological classification in Bay of Biscay. Morpho-sedimentary mapping of the seabed in selected areas. Ifremer, France. De Mol, L., Van Rooij, D., Pirlet, H., Greinert, J., Frank, N., Quemmerais, F., Henriet, J.P., 2011. Cold-water coral habitats in the Penmarc'h and Guilvinec Canyons (Bay of Biscay): Deep-water versus shallow-water settings. Marine Geology 282, 40-52.

Delayat, S., Legrand, V., 2011. Les cantonnements de pêche : (1) Diagnostic général sur la façade Manche Atlantique française. CRPM Basse-Normandie - MAIA, Cherbourg, France. Fabri, M.C., Pedel, L., Beuck, L., Galgani, F., Hebbeln, D., Freiwald, A., 2014. Megafauna of vulnerable marine ecosystems in French mediterranean submarine canyons: Spatial distribution and anthropogenic impacts. Deep-Sea Research Part Ii-Topical Studies in Oceanography 104, 184-207.

Galgani, F., Burgeot, T., Bocquene, G., Vincent, F., Leaute, J.P., Labastie, J., Forest, A., Guichet, R., 1995. DISTRIBUTION AND ABUNDANCE OF DEBRIS ON THE CONTINENTAL-SHELF OF THE BAY OF BISCAY AND IN SEINE BAY. Marine Pollution Bulletin 30, 58-62.

Galgani, F., Hanke, G., Maes, T., 2015. Global Distribution, Composition and Abundance of Marine Litter, in: Bergmann, M., Gutow, L., Klages, M. (Eds.), Marine Anthropogenic Litter. Springer International Publishing, Cham, pp. 29-56.

Galgani, F., Hanke, G., Werner, S., De Vrees, L., 2013. Marine litter within the European Marine Strategy Framework Directive. Ices Journal of Marine Science 70, 1055-1064. Galgani, F., Leaute, J.P., Moguedet, P., Souplet, A., Verin, Y., Carpentier, A., Goraguer, H., Latrouite, D., Andral, B., Cadiou, Y., Mahe, J.C., Poulard, J.C., Nerisson, P., 2000. Litter on the sea floor along European coasts. Marine Pollution Bulletin 40, 516-527.

Galgani, F., Souplet, A., Cadiou, Y., 1996. Accumulation of debris on the deep sea floor off the French Mediterranean coast. Marine Ecology Progress Series 142, 225-234.

Gass, S.E., Roberts, J.M., 2006. The occurrence of the cold-water coral Lophelia pertusa (Scleractinia) on oil and gas platforms in the North Sea: Colony growth, recruitment and environmental controls on distribution. Marine Pollution Bulletin 52, 549-559.

Grehan, A.J., Unnithan, V., Roy, K.O.L., Opderbecke, J., 2005. Fishing impacts on Irish deepwater coral reefs: Making a case for coral conservation, in: Barnes, B.W., Thomas, J.P. (Eds.), Benthic Habitats and the Effects of Fishing, pp. 819-832.

Huvenne, V.A.I., Tyler, P.A., Masson, D.G., Fisher, E.H., Hauton, C., Hühnerbach, V., Le Bas, T.P., Wolff, G.A., 2011. A Picture on the Wall: Innovative Mapping Reveals Cold-Water Coral Refuge in Submarine Canyon. PLoS ONE 6, e28755.

ICES, 2015. Official Nominal Catches 2006-2013. February 2015. Accessed 16-07-2015 via http://ices.dk/marine-data/dataset-collections/Pages/Fish-catch-and-stock-assessment.aspx Jouanneau, J.M., Weber, O., Cremer, M., Castaing, P., 1999. Fine-grained sediment budget on the continental margin of the Bay of Biscay. Deep-Sea Research Part Ii-Topical Studies in Oceanography 46, 2205-2220.

Keller, A.A., Fruh, E.L., Johnson, M.M., Simon, V., McGourty, C., 2010. Distribution and abundance of anthropogenic marine debris along the shelf and slope of the US West Coast. Marine Pollution Bulletin 60, 692-700.

Khripounoff, A., Caprais, J.C., Le Bruchec, J., Rodier, P., Noel, P., Cathalot, C., 2014. Deep cold-water coral ecosystems in the Brittany submarine canyons (Northeast Atlantic): Hydrodynamics, particle supply, respiration, and carbon cycling. Limnology and Oceanography 59, 87-98. 
Kühn, S., Bravo Rebolledo, E.L., Franeker, J.A., 2015. Deleterious Effects of Litter on Marine Life, in: Bergmann, M., Gutow, L., Klages, M. (Eds.), Marine Anthropogenic Litter. Springer International Publishing, Cham, pp. 75-116.

Lorance, P., Leonardi, S., 2011. Contribution thématique DCSMM évaluation de l'état initial "pression et impact" - pression "Abrasion" dans la sous-région marine Méditerranée occidentale DCSMM/EI/MO. Ifremer, France.

Miyake, H., Shibata, H., Furushima, Y., 2011. Deep-sea litter study using deep-sea observation tools. Interdisciplinary studies on environmental Chemistry-Marine environmental modeling and analysis Terrapub, 261-269.

Mordecai, G., Tyler, P.A., Masson, D.G., Huvenne, V.A.I., 2011. Litter in submarine canyons off the west coast of Portugal. Deep-Sea Research Part Ii-Topical Studies in Oceanography 58, 2489-2496.

Mulder, T., Zaragosi, S., Garlan, T., Mavel, J., Cremer, M., Sottolichio, A., Senechal, N., Schmidt, S., 2012. Present deep-submarine canyons activity in the Bay of Biscay (NE Atlantic). Marine Geology 295, 113-127.

Pham, C.K., Gomes-Pereira, J.N., Isidro, E.J., Santos, R.S., Morato, T., 2013. Abundance of litter on Condor seamount (Azores, Portugal, Northeast Atlantic). Deep-Sea Research Part IiTopical Studies in Oceanography 98, 204-208.

Pham, C.K., Ramirez-Llodra, E., Alt, C.H.S., Amaro, T., Bergmann, M., Canals, M., Company, J.B., Davies, J., Duineveld, G., Galgani, F., Howell, K.L., Huvenne, V.A.I., Isidro, E., Jones, D.O.B., Lastras, G., Morato, T., Gomes-Pereira, J.N., Purser, A., Stewart, H., Tojeira, I., Tubau, X., Van Rooij, D., Tyler, P.A., 2014. Marine Litter Distribution and Density in European Seas, from the Shelves to Deep Basins. Plos One 9, e95839.

Priede, I.G., Smith, K.L., Armstrong, J.D., 1990. FORAGING BEHAVIOR OF ABYSSAL GRENADIER FISH - INFERENCES FROM ACOUSTIC TAGGING AND TRACKING IN THE NORTH PACIFIC-OCEAN. Deep-Sea Research Part a-Oceanographic Research Papers 37, 81-101.

Ramirez-Llodra, E., De Mol, B., Company, J.B., Con, M., Sarda, F., 2013. Effects of natural and anthropogenic processes in the distribution of marine litter in the deep Mediterranean Sea. Progress in Oceanography 118, 273-287.

Ramirez-Llodra, E., Tyler, P.A., Baker, M.C., Bergstad, O.A., Clark, M.R., Escobar, E., Levin, L.A., Menot, L., Rowden, A.A., Smith, C.R., Van Dover, C.L., 2011. Man and the last great wilderness: human impact on the deep sea. PLoS One 6, e22588.

Reveillaud, J., Freiwald, A., Van Rooij, D., Le Guilloux, E., Altuna, A., Foubert, A., Vanreusel, A., Roy, K.O.L., Henriet, J.P., 2008. The distribution of scleractinian corals in the Bay of Biscay, NE Atlantic. Facies 54, 317-331.

Roberts, J.M., Wheeler, A.J., Freiwald, A., 2006. Reefs of the deep: The biology and geology of cold-water coral ecosystems. Science 312, 543-547.

Ryan, P.G., 2015. A Brief History of Marine Litter Research, in: Bergmann, M., Gutow, L., Klages, M. (Eds.), Marine Anthropogenic Litter. Springer International Publishing, Cham, pp. $1-25$.

Sanchez, F., Morandeau, G., Bru, N., Lissardy, M., 2013. A restricted fishing area as a tool for fisheries management: Example of the Capbreton canyon, southern Bay of Biscay. Marine Policy 42, 180-189.

Schlining, K., von Thun, S., Kuhnz, L., Schlining, B., Lundsten, L., Stout, N.J., Chaney, L., Connor, J., 2013. Debris in the deep: Using a 22-year video annotation database to survey marine litter in Monterey Canyon, central California, USA. Deep-Sea Research Part IOceanographic Research Papers 79, 96-105.

Schmidt, S., Howa, H., Diallo, A., Martin, J., Cremer, M., Duros, P., Fontanier, C., Deflandre, B., Metzger, E., Mulder, T., 2014. Recent sediment transport and deposition in the Cap-Ferret 
Canyon, South-East margin of Bay of Biscay. Deep-Sea Research Part Ii-Topical Studies in Oceanography 104, 134-144.

Sulak, K.J., Brooks, R.A., Luke, K.E., Norem, A.D., Randall, M., Quaid, A.J., Yeargin, G.E., Miller, J.M., Harden, W.M., Caruso, J.H., Ross, S.W., 2007. Demersal fishes associated with Lophelia pertusa coral and hard-substrate biotopes on the continental slope, northern Gulf of Mexico, in: George, R.Y., Cairns, S.D. (Eds.), Conservation and Adaptive Management of Seamount and Deep-Sea Coral Ecosystems, pp. 65-92.

Thompson, R.C., Olsen, Y., Mitchell, R.P., Davis, A., Rowland, S.J., John, A.W.G., McGonigle, D., Russell, A.E., 2004. Lost at sea: Where is all the plastic? Science 304, 838838.

Tubau, X., Canals, M., Lastras, G., Rayo, X., Rivera, J., Amblas, D., 2015. Marine litter on the floor of deep submarine canyons of the Northwestern Mediterranean Sea: The role of hydrodynamic processes. Progress in Oceanography 134, 379-403.

Van Rooij, D., De Mol, L., Le Guilloux, E., Wisshak, M., Huvenne, V.A.I., Moeremans, R., Henriet, J.P., 2010. Environmental setting of deep-water oysters in the Bay of Biscay. DeepSea Research Part I-Oceanographic Research Papers 57, 1561-1572.

Vieira, R.P., Raposo, I.P., Sobral, P., Goncalves, J.M.S., Bell, K.L.C., Cunha, M.R., 2015. Lost fishing gear and litter at Gorringe Bank (NE Atlantic). Journal of Sea Research 100, 9198.

Watters, D.L., Yoklavich, M.M., Love, M.S., Schroeder, D.M., 2010. Assessing marine debris in deep seafloor habitats off California. Marine Pollution Bulletin 60, 131-138.

Wei, C.L., Rowe, G.T., Nunnally, C.C., Wicksten, M.K., 2012. Anthropogenic "Litter" and macrophyte detritus in the deep Northern Gulf of Mexico. Marine Pollution Bulletin 64, 966973.

Williams, A., Schlacher, T.A., Rowden, A.A., Althaus, F., Clark, M.R., Bowden, D.A.,

Stewart, R., Bax, N.J., Consalvey, M., Kloser, R.J., 2010. Seamount megabenthic assemblages fail to recover from trawling impacts. Marine Ecology-an Evolutionary

Perspective 31, 183-199.

Woodall, L.C., Robinson, L.F., Rogers, A.D., Narayanaswamy, B.E., Paterson, G.L.J., 2015. Deep sea litter: A comparison of seamounts, banks and a ridge in the Atlantic and Indian Oceans reveals both environmental and anthropogenic factors impact accumulation and composition. Frontiers in Marine Science 2. 
Table 1: The number of litter, litter densities and main characteristics of the dive surveyed with the towed camera Scampi (BobGeo and BobGeo 2) or the ROV Victor 6000 (BobEco). The names of the canyons are listed from north to south. Litter densities per canyon are given in bold; it consists of the results of one dive if there was only one dive performed in that specific canyon or it consists of the mean between several dives when multiple were undertaken in one canyon. Standard deviations are provided between brackets, if possible. Mean values for the Bay of Biscay are also provided.

Table 2: Details of the items allocated to each category: 'Plastics', 'Fishing-related items', 'Cables \& ropes' and 'Other items'. The category 'Glass bottles' needs no further description, because only glass bottles were included in this category. The 'Unidentified items' are not described further either, because they were, by definition, impossible to identify. Individual items are listed in alphabetical order.

Table 3: Litter densities (in items 100 images $^{-1}$ ), the percentages of images showing at least one item of litter and the total number of images for each area of relief: "corals", "other biological species", "geological features" and "bare substratum".

Table 4: The different biological and geological structures forming each relief category. 
Figure 1: Examples of marine litter; each representing one of six categories: A) "Plastic items" (BobGeo 2 cruise); B) "Cables and ropes" (BobEco cruise); C) "Fishing-related items" (BobGeo 2 cruise); D) "Glass bottles" (BobEco cruise) and E) "Other items" (BobEco cruise).

Figure 2: The proportion items corresponding to each category in the Bay of Biscay (205 items in total).

Figure 3: The distribution and composition of litter in the canyons of the Bay of Biscay. The pie charts represent the proportion of each litter category among the total items found in the canyon concerned:

Figure 4: The percentages of images showing signs of litter, from the total number $(n)$ of images per 300-m depth class.

Figure 5: The number of items allocated to each litter category within the different seafloor structures.

Figure 6: The distribution of seafloor structures within each depth class. 
Table 1: The number of litter, litter densities and main characteristics of the dive surveyed with the towed camera Scampi (BobGeo and BobGeo 2) or the ROV Victor 6000 (BobEco). The names of the canyons are listed from north to south. Litter densities per canyon are given in bold; it consists of the results of one dive if there was only one dive performed in that specific canyon or it consists of the mean between several dives when multiple were undertaken in one canyon. Standard deviations are provided between brackets, if possible. Mean values for the Bay of Biscay are also provided.

\begin{tabular}{|c|c|c|c|c|c|c|c|c|c|}
\hline Canyon & Cruise & Dive & $\begin{array}{c}\text { Av. } \\
\text { Depth } \\
\text { (m) }\end{array}$ & $\begin{array}{c}\text { Min. } \\
\text { depth } \\
\text { (m) }\end{array}$ & $\begin{array}{c}\text { Max. } \\
\text { depth } \\
\text { (m) }\end{array}$ & $\begin{array}{l}\text { Length } \\
(\mathrm{km})\end{array}$ & $\begin{array}{l}\text { Tot no. } \\
\text { Images }\end{array}$ & $\begin{array}{c}\text { No. } \\
\text { litter } \\
\text { items }\end{array}$ & $\begin{array}{c}\text { No. } \\
\text { items } \\
\text { per } 100 \\
\text { image }\end{array}$ \\
\hline Sorlingues & BobEco & 477 & 746.6 & 381.4 & 1240.5 & 9.21 & 588 & 3 & 0.5 \\
\hline Sorlingues & BobEco & 472 & 1598.2 & 1095.6 & 2358.6 & 2.94 & 180 & 0 & 0 \\
\hline $\begin{array}{c}\text { Sorlingues } \\
\text { (mean) }\end{array}$ & & & & & & $\begin{array}{c}6.07 \\
( \pm 4.43)\end{array}$ & $\begin{array}{c}384 \\
( \pm 288)\end{array}$ & $\begin{array}{c}1.5 \\
( \pm 2.1)\end{array}$ & 0.4 \\
\hline Petite Sole & BobEco & 471 & 794.8 & 657.7 & 1000.4 & 7.86 & 458 & 6 & 1.3 \\
\hline Petite Sole & BobEco & 476 & 955.0 & 943.0 & 964.9 & 2.63 & 199 & 3 & 1.5 \\
\hline $\begin{array}{c}\text { Petite Sole } \\
\text { (mean) }\end{array}$ & & & & & & $\begin{array}{c}5.25 \\
( \pm 3.70)\end{array}$ & $\begin{array}{c}329 \\
( \pm 183)\end{array}$ & $\begin{array}{c}4.5 \\
( \pm 2.1)\end{array}$ & 1.4 \\
\hline Lampaul & BobEco & 478 & 805.2 & 509.1 & 1249.9 & 11.13 & 516 & 8 & 1.6 \\
\hline Shelf-N & BobGeo & 1 & 291.5 & 223.4 & 353.9 & 2.05 & 97 & 2 & 2.1 \\
\hline Chapelle & BobGeo & 3 & 467.1 & 426.9 & 527.4 & 0.80 & 20 & 0 & 0 \\
\hline Chapelle & BobGeo & 4 & 784.8 & 560.3 & 1062.2 & 1.61 & 100 & 1 & 1.0 \\
\hline Chapelle & BobGeo & 2 & 621.9 & 404.0 & 1082.0 & 2.93 & 150 & 2 & 1.3 \\
\hline $\begin{array}{c}\text { Chapelle } \\
\text { (mean) }\end{array}$ & 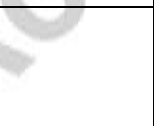 & & & & & $\begin{array}{c}1.78 \\
( \pm 1.08)\end{array}$ & $\begin{array}{c}90 \\
( \pm 66)\end{array}$ & $\begin{array}{c}1.0 \\
( \pm 1.0)\end{array}$ & 1.1 \\
\hline Crozon & BobEco & 479 & 929.9 & 673.9 & 1385.7 & 10.07 & 492 & 12 & 2.4 \\
\hline Morgat & BobGeo & 5 & 742.4 & 418.3 & 1205.4 & 4.00 & 280 & 29 & 10.4 \\
\hline Morgat & BobGeo & 6 & 707.8 & 572.9 & 915.8 & 1.06 & 81 & 3 & 3.7 \\
\hline $\begin{array}{l}\text { Morgat } \\
\text { (mean) }\end{array}$ & & & & & & $\begin{array}{c}2.53 \\
( \pm 2.08)\end{array}$ & $\begin{array}{c}181 \\
( \pm 141)\end{array}$ & $\begin{array}{c}16 \\
( \pm 18.4)\end{array}$ & 8.9 \\
\hline $\begin{array}{c}\text { Morgat - } \\
\text { Douarnenez }\end{array}$ & BobEco & 480 & 880.9 & 704.6 & 1201.3 & 8.50 & 388 & 14 & 3.6 \\
\hline Guilvinec & BobEco & 469 & 877.0 & 790.5 & 923.9 & 4.71 & 303 & 15 & 5.0 \\
\hline
\end{tabular}




\begin{tabular}{|c|c|c|c|c|c|c|c|c|c|}
\hline Odet & $\begin{array}{c}\text { BobGeo } \\
2\end{array}$ & 6 & 700.9 & 345.2 & 1172.3 & 6.66 & 352 & 9 & 2.6 \\
\hline Odet & BobGeo & 10 & 722.0 & 625.5 & 897.4 & 1.48 & 86 & 0 & 0 \\
\hline Odet & BobGeo & 7 & 880.9 & 645.9 & 1320.9 & 2.83 & 213 & 7 & 3.3 \\
\hline Odet & BobGeo & 9 & 710.1 & 542.9 & 917.6 & 2.15 & 140 & 1 & 0.7 \\
\hline $\begin{array}{c}\text { Odet } \\
\text { (mean) }\end{array}$ & & & & & & $\begin{array}{c}3.28 \\
( \pm 2.32)\end{array}$ & $\begin{array}{c}198 \\
( \pm 115)\end{array}$ & $\begin{array}{c}4.3 \\
( \pm 4.4)\end{array}$ & 2.1 \\
\hline Shelf-S & $\begin{array}{c}\text { BobGeo } \\
2\end{array}$ & 5 & 228.4 & 227.1 & 229.1 & 0.99 & 56 & 2 & 3.6 \\
\hline Shelf-S & BobGeo & 8 & 334.8 & 293.4 & 393.3 & 2.71 & 173 & 11 & 6.4 \\
\hline $\begin{array}{l}\text { Shelf-S } \\
\text { (mean) }\end{array}$ & & & & & & $\begin{array}{c}1.85 \\
( \pm 1.22)\end{array}$ & $\begin{array}{c}115 \\
( \pm 83)\end{array}$ & $\begin{array}{c}6.5 \\
( \pm 6.4)\end{array}$ & 5.7 \\
\hline Belle-île & BobGeo & 11 & 681.5 & 418.8 & 987.8 & 2.09 & 143 & 18 & 12.6 \\
\hline Croisic & BobEco & 468 & 836.1 & 711.9 & 940.3 & 2.97 & 197 & 1 & 0.5 \\
\hline St. Nazaire & BobEco & 467 & 1495.5 & 1148.1 & 1763.2 & 2.15 & 129 & 5 & 3.9 \\
\hline Rochebonne & BobEco & 465 & 949.8 & 587.2 & 1498.6 & 3.25 & 134 & 5 & 3.7 \\
\hline Ars & BobEco & 466 & 801.8 & 517.1 & 1094.7 & 2.90 & 172 & 1 & 0.6 \\
\hline Ars & $\begin{array}{c}\text { BobGeo } \\
2\end{array}$ & 1 & 717.6 & 463.3 & 1196.5 & 5.16 & 207 & 2 & 1.0 \\
\hline $\begin{array}{c}\text { Ars } \\
\text { (mean) }\end{array}$ & & & & $\nabla$ & & $\begin{array}{c}4.03 \\
( \pm 1.59)\end{array}$ & $\begin{array}{c}190 \\
( \pm 25)\end{array}$ & $\begin{array}{c}1.5 \\
( \pm 0.7)\end{array}$ & 0.8 \\
\hline Arcachon & $\begin{array}{c}\text { BobGeo } \\
2\end{array}$ & 2 & 1261.4 & 1103.6 & 1534.4 & 5.21 & 151 & 0 & 0.0 \\
\hline Arcachon & $\begin{array}{c}\text { BobGeo } \\
2\end{array}$ & 3 & 1392.9 & 1261.4 & 1517.1 & 4.35 & 76 & 30 & 39.5 \\
\hline Arcachon & $\begin{array}{c}\text { BobGeo } \\
2\end{array}$ & 4 & 933.6 & 768.9 & 1086.8 & 4.52 & 174 & 8 & 4.6 \\
\hline $\begin{array}{c}\text { Arcachon } \\
\text { (mean) }\end{array}$ & & & & & & $\begin{array}{c}4.69 \\
( \pm 0.46)\end{array}$ & $\begin{array}{c}134 \\
( \pm 51)\end{array}$ & $\begin{array}{c}12.7 \\
( \pm 15.5)\end{array}$ & 9.5 \\
\hline $\begin{array}{l}\text { Bay of } \\
\text { Biscay }\end{array}$ & & & 836.4 & 223.4 & 2358.6 & $\begin{array}{c}119 \\
\text { (total) }\end{array}$ & $\begin{array}{c}6255 \\
\text { (total) }\end{array}$ & $\begin{array}{c}198 \\
\text { (total) }\end{array}$ & $\begin{array}{c}3.2 \\
\text { (mean) }\end{array}$ \\
\hline
\end{tabular}


Table 2: Details about the items allocated to each category 'Plastics', 'Fishing-related items', 'Cables and ropes' and 'Other items'. The category 'Glass bottles' does not need to be detailed, since only glass bottles are allocated to this category. The items in 'Unidentified items' are not specified neither, since it was impossible to identify these items. Individual items are in alphabetical order.

\begin{tabular}{|l|l|l|l|}
\hline Plastic & Fishing-related items & Cables \& ropes & Other items \\
\hline Bags & Gill- or trawl nets & Cables & Artillery \\
\hline Fake Christmas tree & Longlines & Ropes & Ceramic cups \\
\hline Hard plastics & Mesh & Wires & Ceramic plates \\
\hline Sheets & Parts of fishing gear & & Cloth/fabrics \\
\hline Tubes & Traps & & Metal drinking cans \\
\hline & & & Metal items \\
\hline & & & Metal pipe \\
\hline & & & Rubber tubes \\
\hline
\end{tabular}


Table 3: The different biological and geological structures constructing each relief-category.

\begin{tabular}{|c|c|c|c|}
\hline Coral & $\begin{array}{c}\text { Other biological } \\
\text { species }\end{array}$ & Geological structures & Bare sediment \\
\hline Antipatharians & Actiniaria & Boulders & Consolidated mud \\
\hline Gorgonians & Brachiopoda & Cobbles & Gravel \\
\hline Scleractinians & Cerianthids & Pebbles & Hard substrate \\
\hline $\begin{array}{c}\text { Scleractinian rubble } \\
\text { Seapens }\end{array}$ & $\begin{array}{c}\text { Oysters } \\
\text { Oyster and other shell } \\
\text { debris }\end{array}$ & $\begin{array}{c}\text { Rocky outcrops } \\
\text { the }\end{array}$ & Soft sediment \\
\hline $\begin{array}{c}\text { Mix of two or more of } \\
\text { the above }\end{array}$ & Sponges & Ledges & \\
\hline $\begin{array}{c}\text { Mix of corals and } \\
\text { xenophyophores }\end{array}$ & Xenophyophores & Steps & \\
\hline & & Very high slope & \\
\hline
\end{tabular}


Table 4: The litter densities, percentages of images showing one or more items of litter and the total number of images for each relief-areas: "Corals", "other biological species", "geological features" and "bare substratum".

\begin{tabular}{|c|c|c|c|c|}
\hline Relief-type & $\begin{array}{c}\text { Total number } \\
\text { of images }\end{array}$ & $\begin{array}{c}\text { Number of images } \\
\text { showing litter }\end{array}$ & $\begin{array}{c}\text { Litter density } \\
\text { (items 100 images }^{-1} \text { ) }\end{array}$ & $\begin{array}{c}\text { Percentage images } \\
\text { showing litter }\end{array}$ \\
\hline Coral & 2216 & 85 & 4.5 & 3.9 \\
\hline $\begin{array}{c}\text { Other biological } \\
\text { species }\end{array}$ & 345 & 5 & 1.4 & 1.5 \\
\hline $\begin{array}{c}\text { Geological } \\
\text { structures }\end{array}$ & 443 & 19 & 9.9 & 4.3 \\
\hline Bare substratum & 3251 & 42 & 1.5 & 1.3 \\
\hline
\end{tabular}



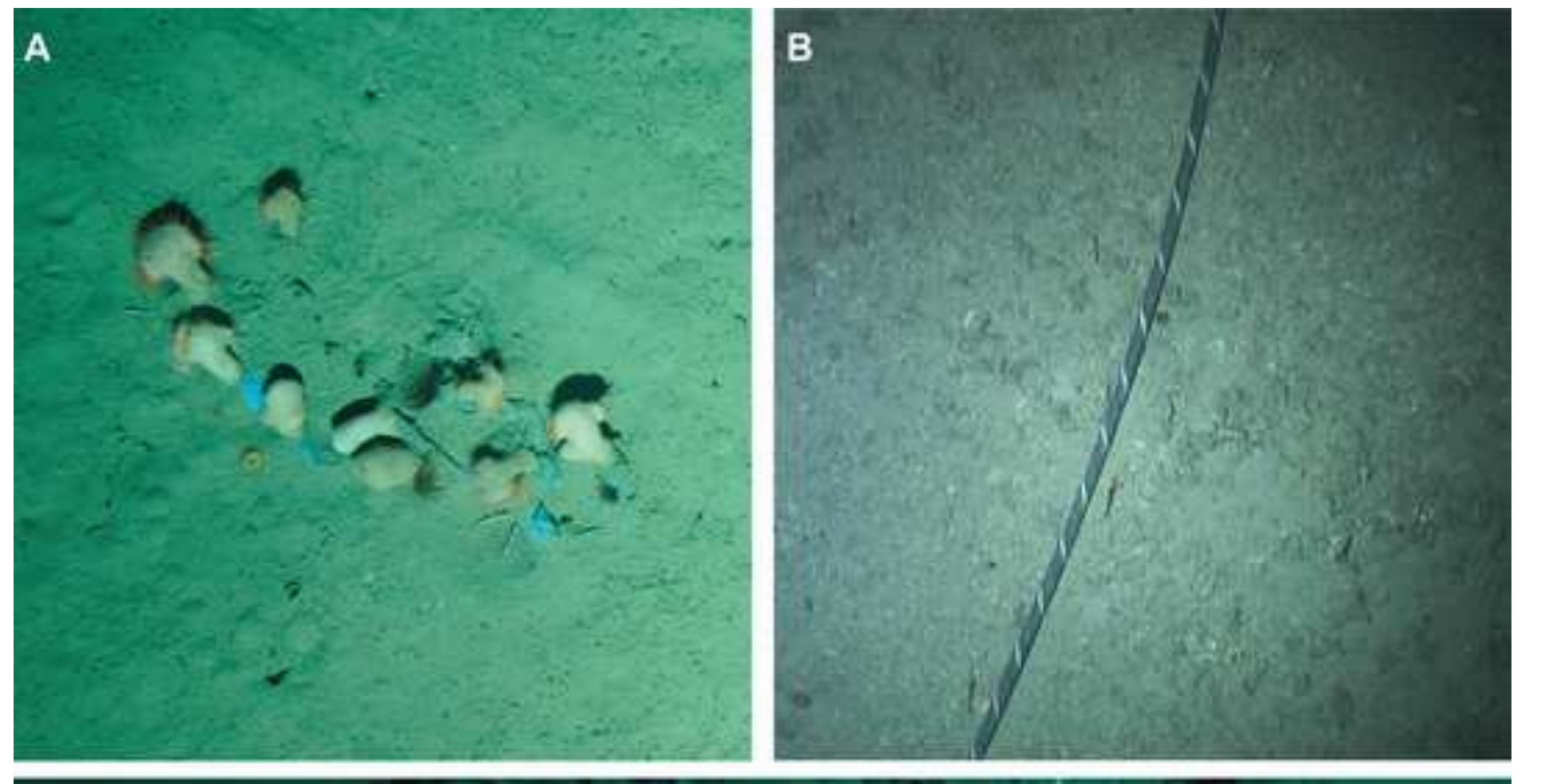

C
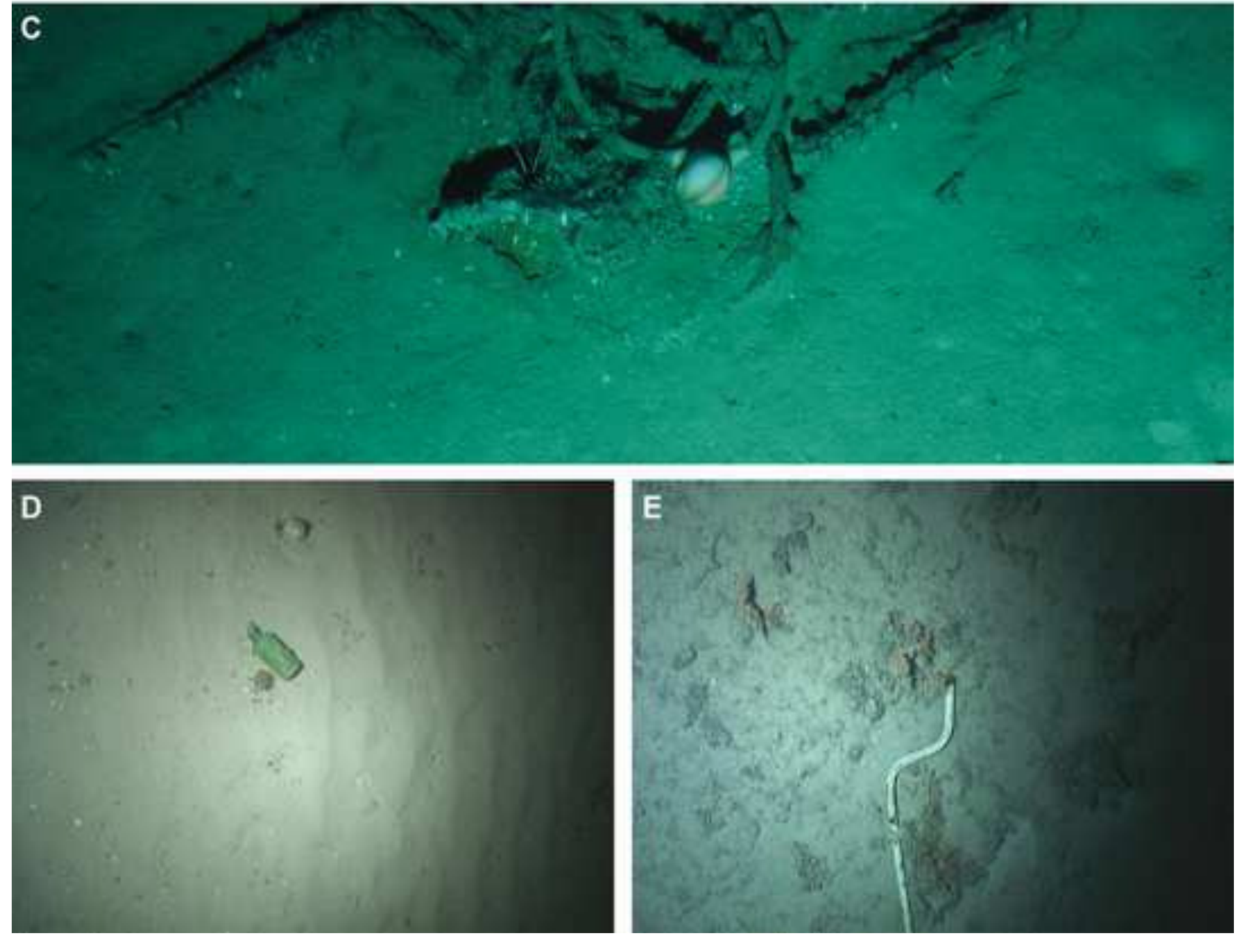

\begin{tabular}{l|l} 
Figure 1 & ACCEPTED MANUSCRIPT
\end{tabular}
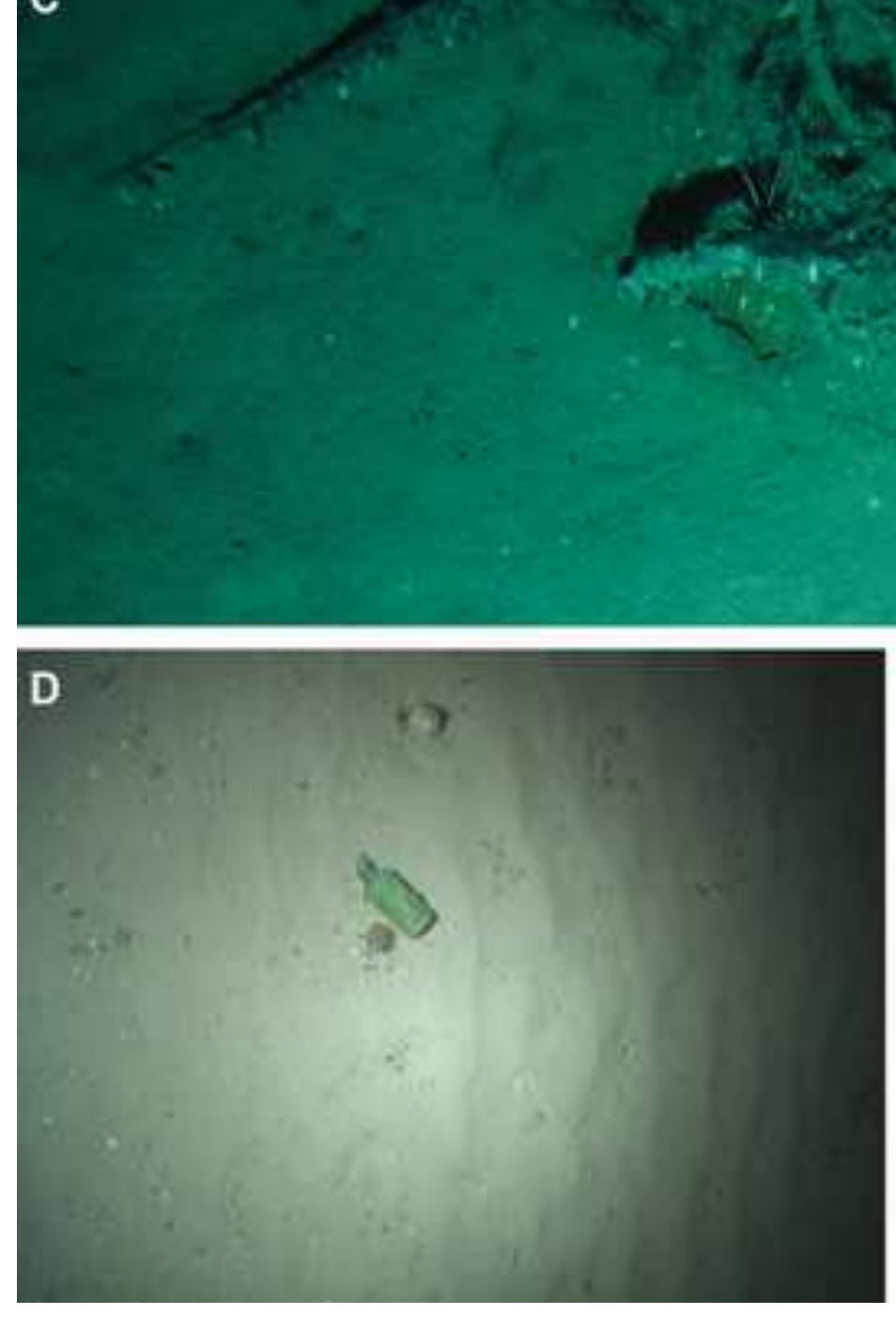

Figure 1
$A C C E P T E D$ MANUSCRIPT
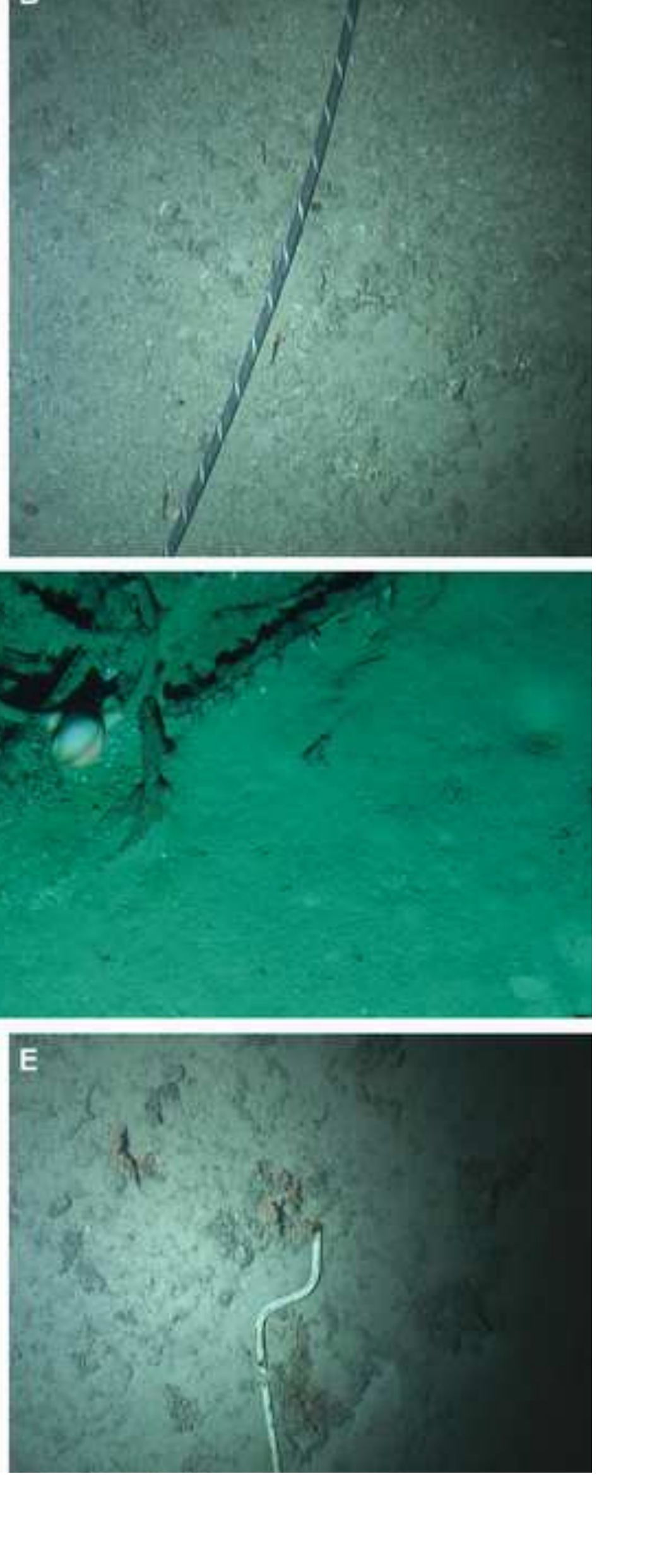

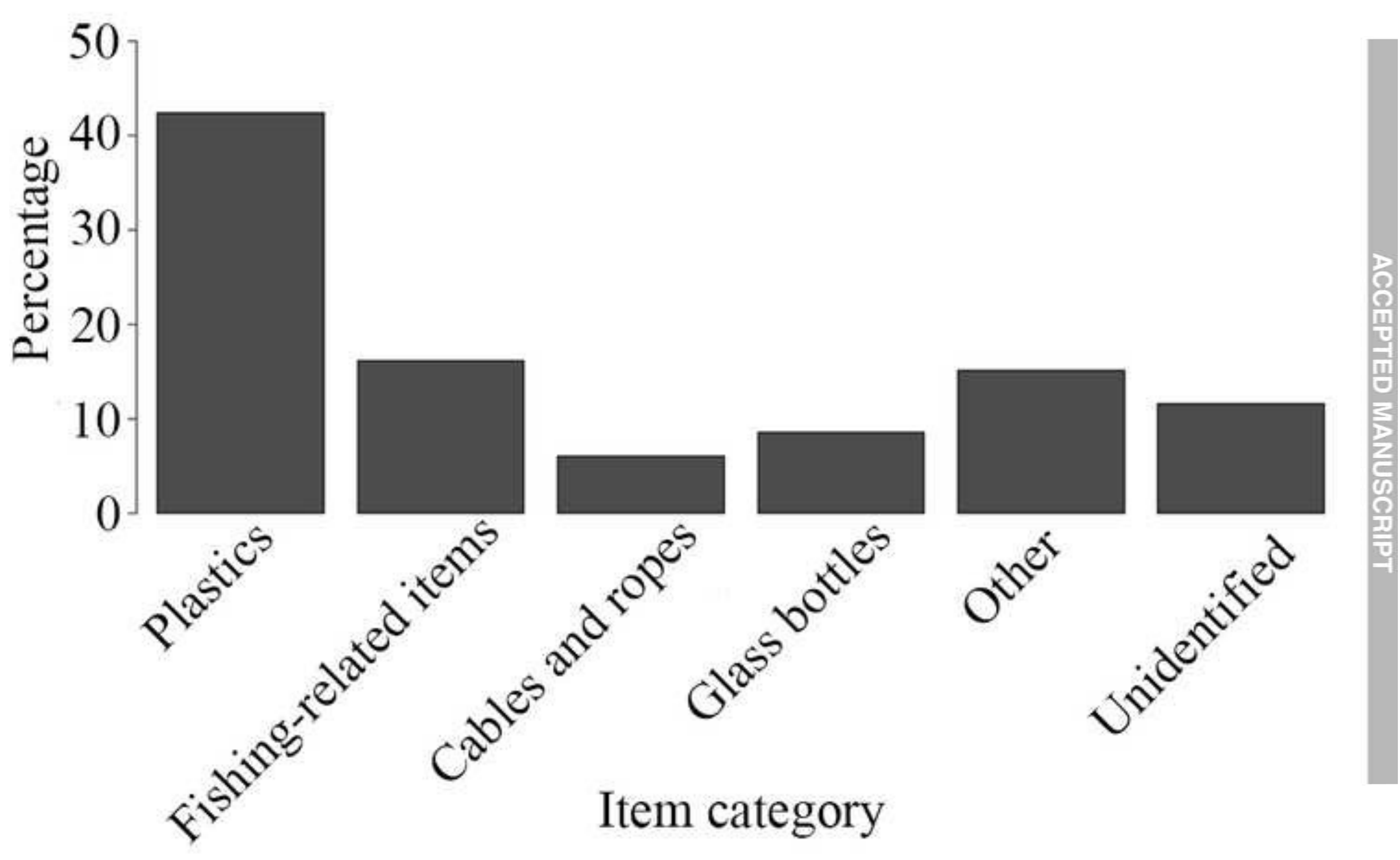


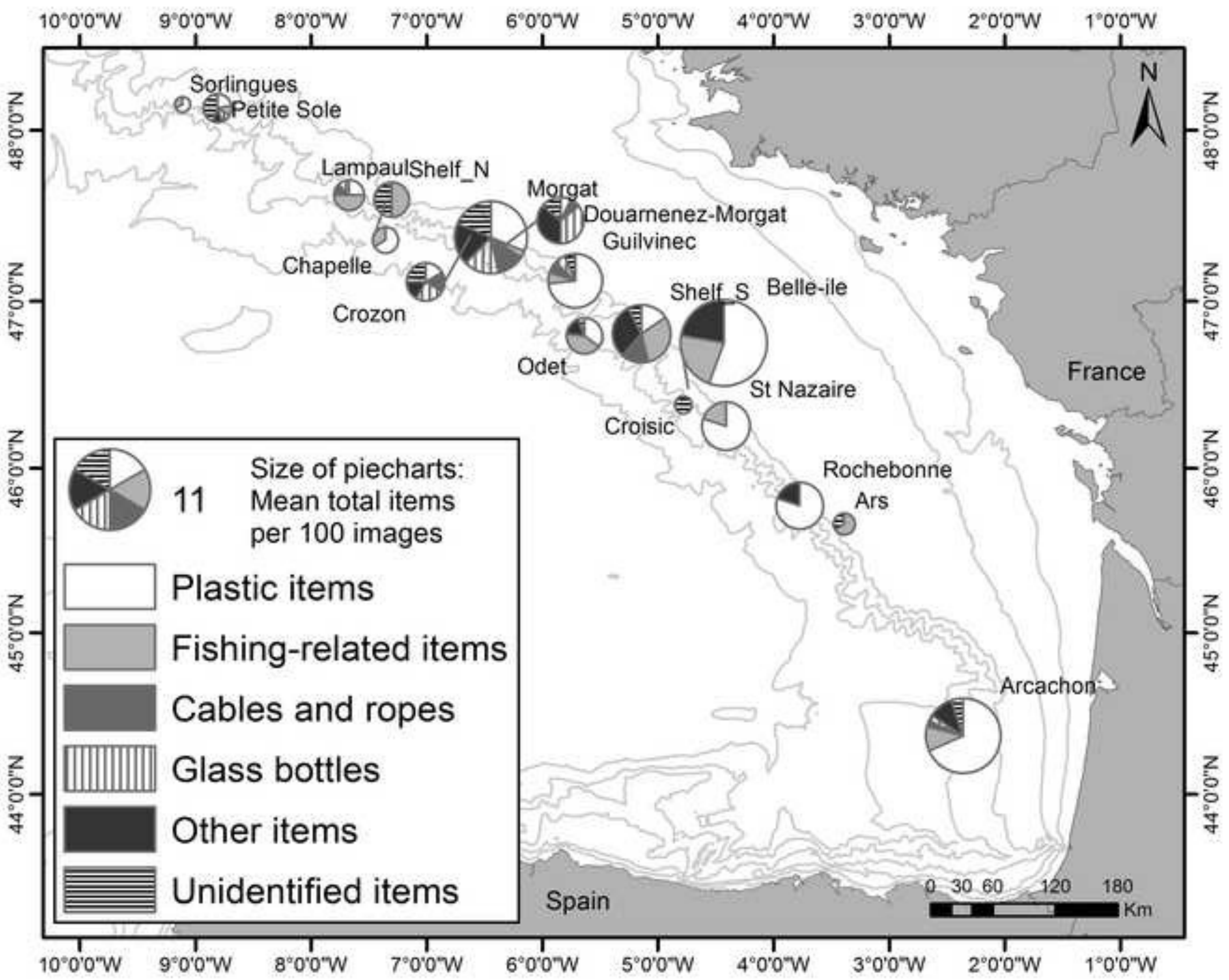




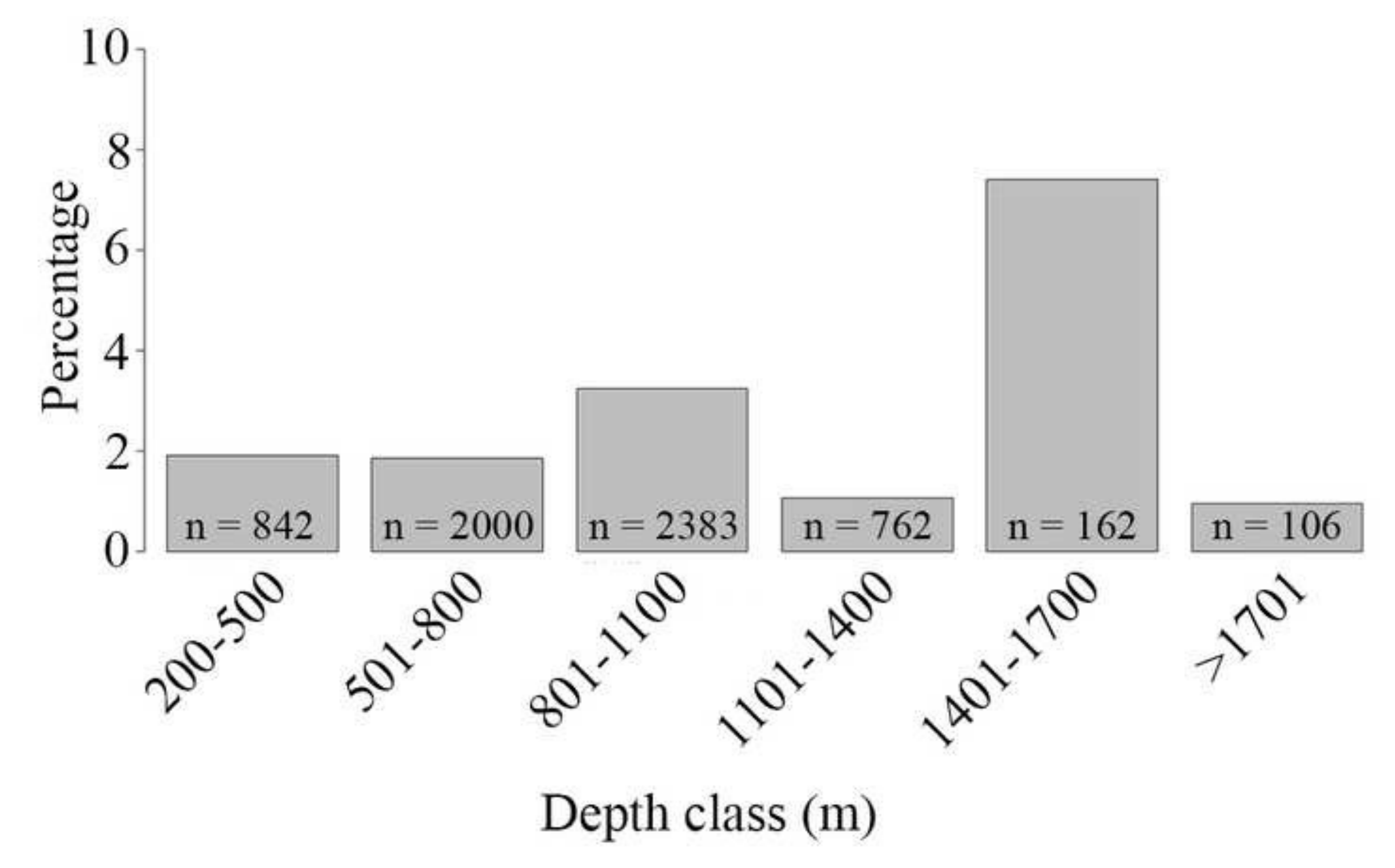

Depth class (m)

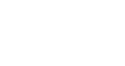



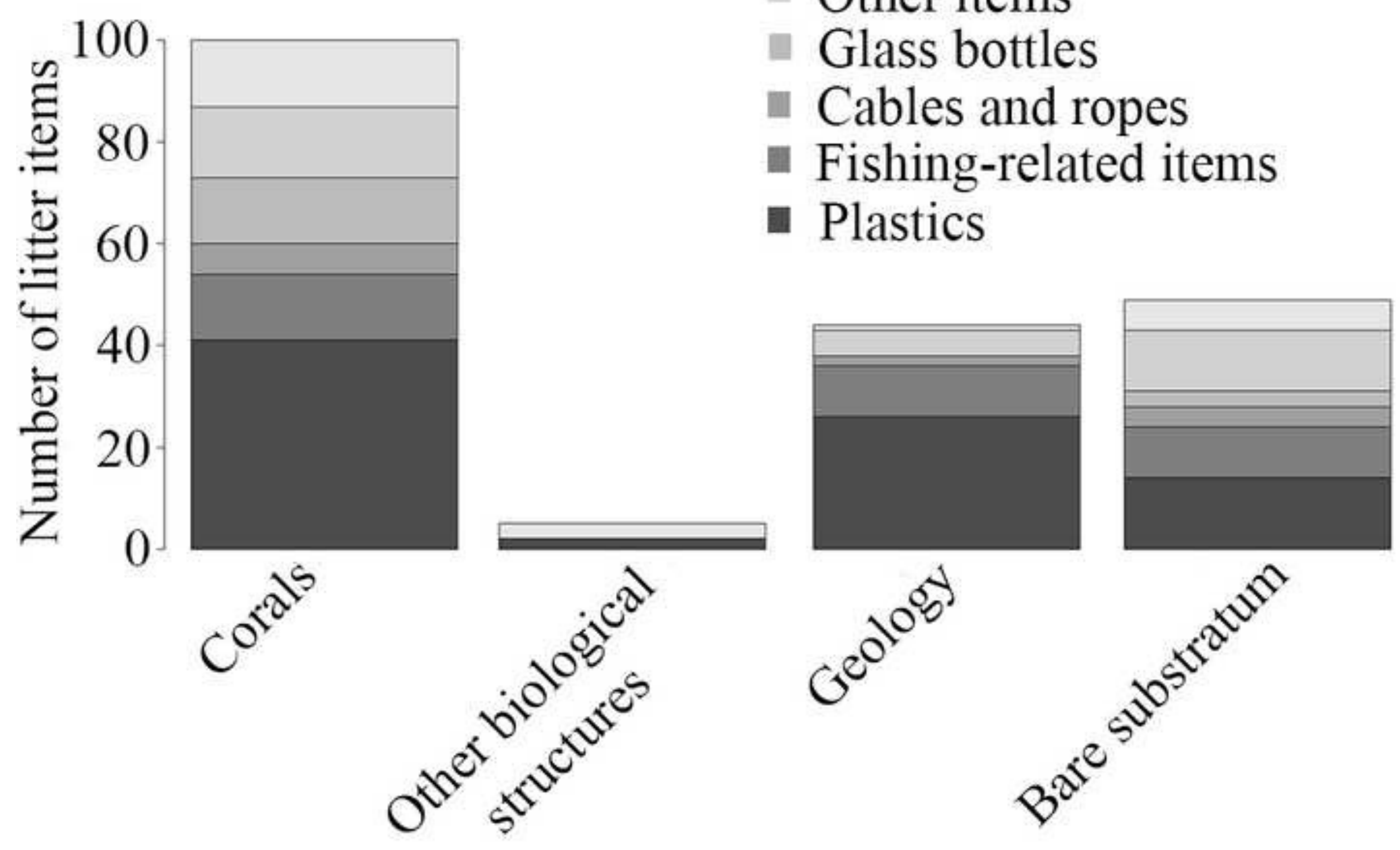

Seafloor structures 


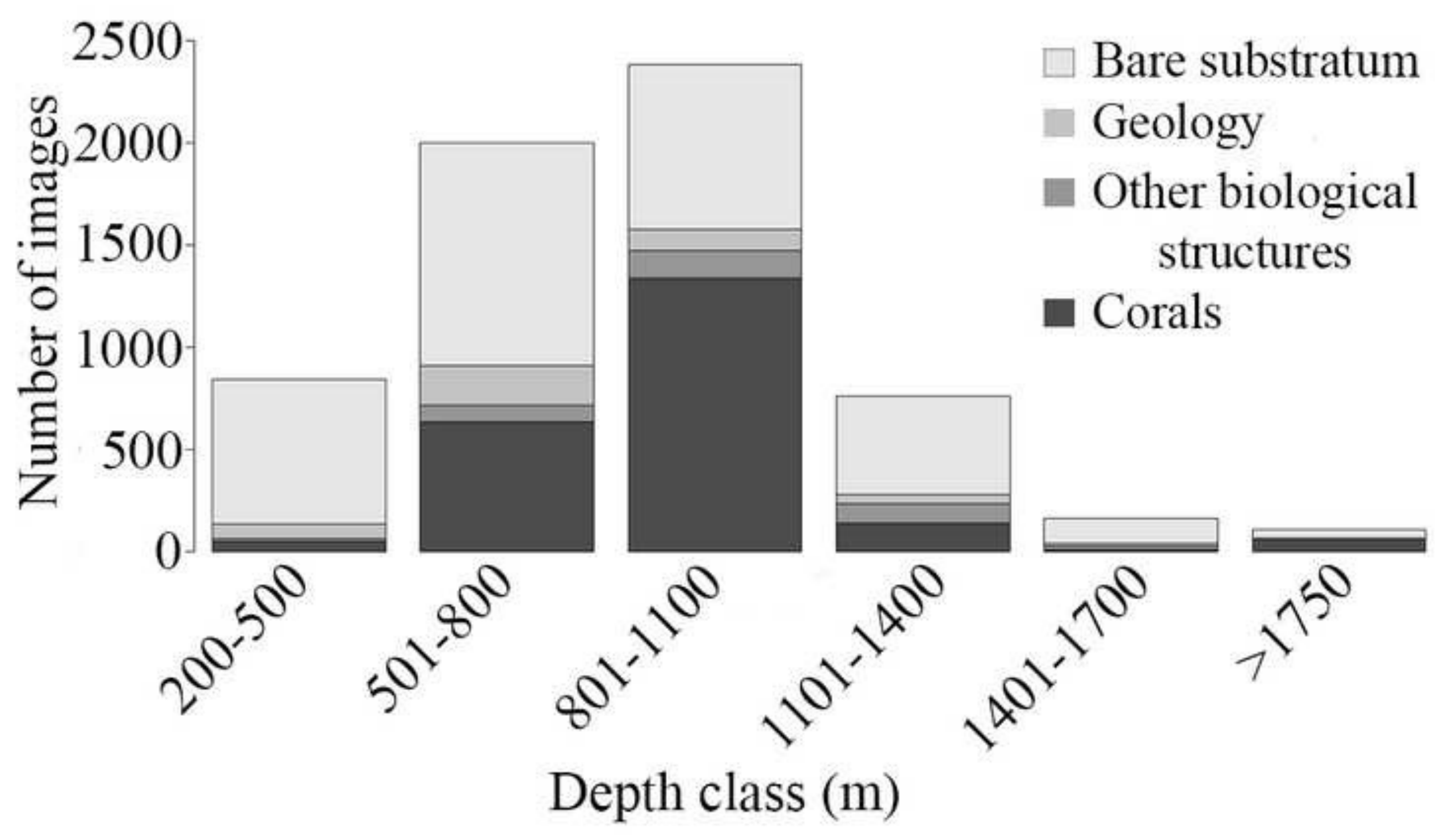

